
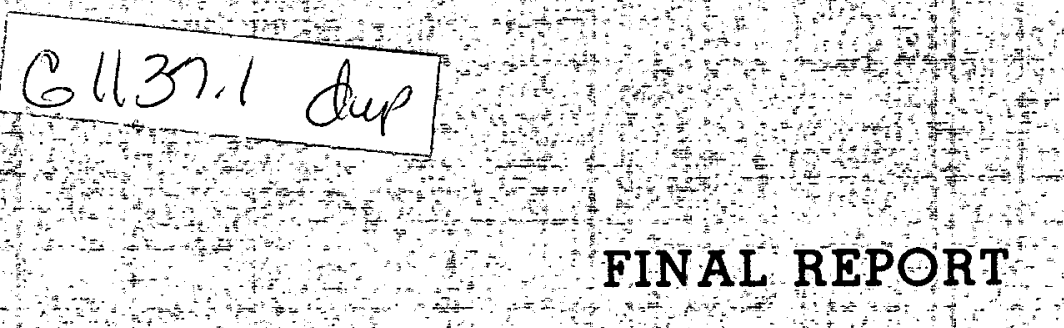

FIN AL REPORT

PHASE II GEOTHERMAL EXPLORATION

and

GEOTHERMAL POWER PLANT UPDATE

FOR ASCENSION ISLAND,

SOUTH ATLANTIC OCEAN

prepared or

UNITED STATES AIR FORCE

EASTERN SPACE AND MISSILE CENTER

PATRICK AIR FORCE BASE, FLORIDA

Fo

and

UNITED STATES DEPARTMENT OF ENERGY

IDAHO OPERATIONS OFFICE

IDAHO FALLS, IDAHO

by

EARTH SCIENCE LABORATORY

UNIVERSITY Of UTAH RESEARCH INSTITUTE

and

EG\&G, IDAHO, INCORPOR ATED

LNEGRG

Idaho. Inc
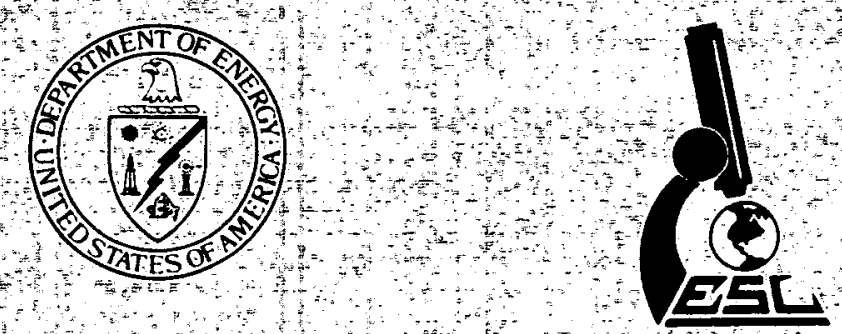

JULY 12,1984 


\section{DISCLAIMER}

This report was prepared as an account of work sponsored by an agency of the United States Government. Neither the United States Government nor any agency Thereof, nor any of their employees, makes any warranty, express or implied, or assumes any legal liability or responsibility for the accuracy, completeness, or usefulness of any information, apparatus, product, or process disclosed, or represents that its use would not infringe privately owned rights. Reference herein to any specific commercial product, process, or service by trade name, trademark, manufacturer, or otherwise does not necessarily constitute or imply its endorsement, recommendation, or favoring by the United States Government or any agency thereof. The views and opinions of authors expressed herein do not necessarily state or reflect those of the United States Government or any agency thereof. 


\section{DISCLAIMER}

Portions of this document may be illegible in electronic image products. Images are produced from the best available original document. 


\title{
FINAL REPORT \\ GEOTHERMAL EXPLORATION AND \\ GEOTHERMAL POWER PLANT UPDATE \\ FOR ASCENSION ISLAND, \\ SOUTH ATLANTIC OCEAN
}

\author{
Prepared for \\ United States Air Force \\ Eastern Space and Missile Center \\ Patrick Air Force Base, \\ Florida \\ and \\ United States Department of Energy \\ Idaho Falls Operations office \\ Idaho Falls, Idaho
}

by

Earth Science Laboratory

University of Utah Research Institute

Dennis L. Nielson

Bruce S. Sibbett

and

EG\&G, Idaho, Inc.

M. K. Shane

J. F. Whitbeck 


\section{NOTICE}

This report was prepared to document work sponsored by the United States Government. Neither the United States nor its agent, the United States Department of Energy, nor any Federal employees, nor any of their contractors, subcontractors or their employees, makes any warranty, express or implied, or assumes any legal liability or responsibility for the accuracy, completeness, or usefulness of any information, apparatus, product or process disclosed, or represents that its use would not infringe privately owned rights.

\section{NOT ICE}

Reference to a company or product name does not imply approval or recommendation of the product by the University of Utah Research Institute or the U.S. Department of Energy to the exclusion of others that may be suitable. 


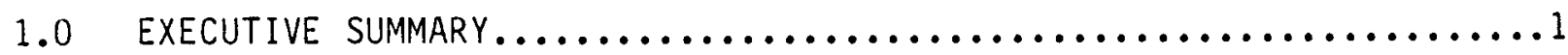

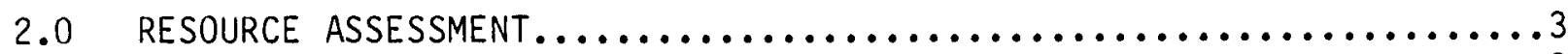

2.1 Geothermat Exploration................................

2.1.1 Electrical Resistivity..........................6

2.1.2 Aeromagnetic Survey..........................

2.1.3 Thermal Gradient Drilling and Measurements...........10

2.2 Data Synthesis.....................................

3.0 GEOTHERMAL POWER PLANT UPDATE.............................20

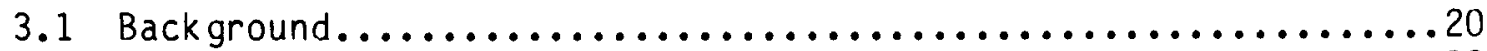

3.2 Resource Development and Use...........................22

3.2.1 Power Cycle Options and Assumptions................24

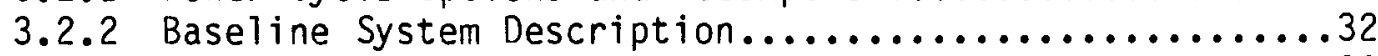

3.2.2.1 Geothermal Supply System...................32

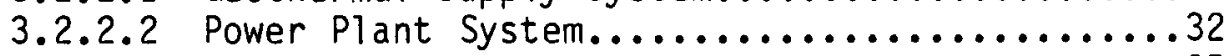

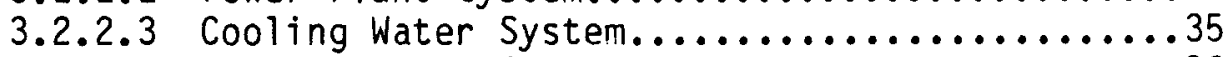

3.2.2.4 Potable Water System........................

3.2.2.5 Waste Water System.....................36

3.2.3 Baseline System Costs and Economics.................37

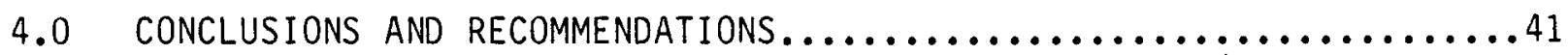

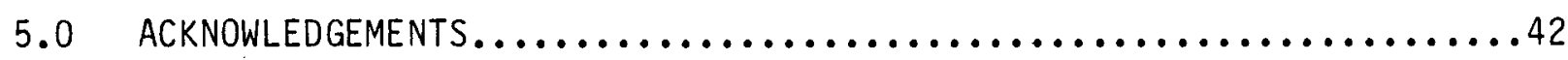

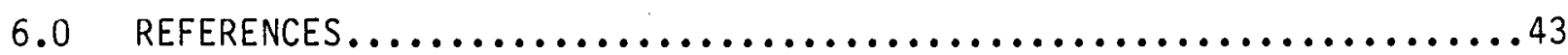


$\underline{\text { Page }}$

Figure 1. Exploration Strategy...........................

Figure 2. Electrical Resistivity Results.....................

Figure 3. Aeromagnetic Survey Results and Drill Hole Locations..........11

Figure 4. Temperature Gradients Plotted Against Elevation............13

Figure 5. Estimates of Temperatures as a Function of Depth..........16

Figure 6. Conceptual Models of Geothermal System Beneath............18 Ascension Island.

Figure 7. Ascension Island -- Areas of Interest..................23

Figure 8. Well Depth Versus Fractional Change in Cost..............25

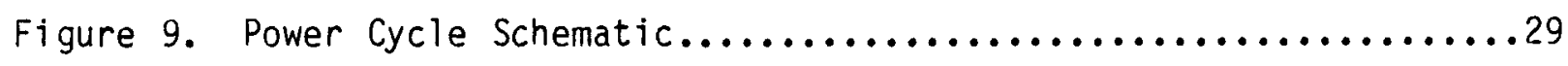

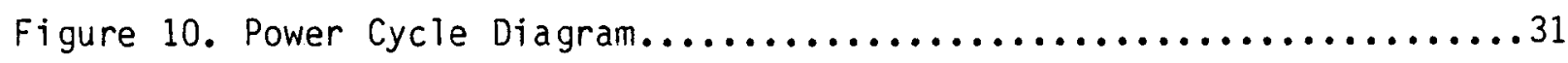

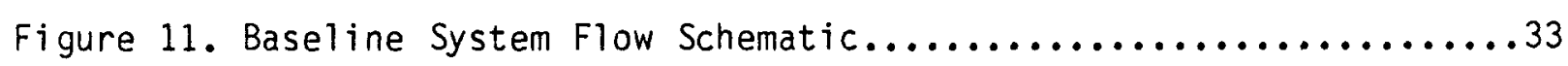




\section{LIST OF TABLES}

Page

Table 1 - Chemical Analyses of Fluids from LDTGH......................

Table 2 - Preliminary Estimate of Geothermal Reservoir Parameters,...... 19 Ascension Island

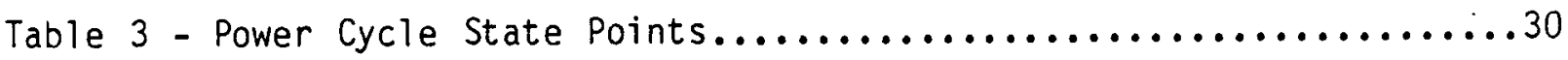

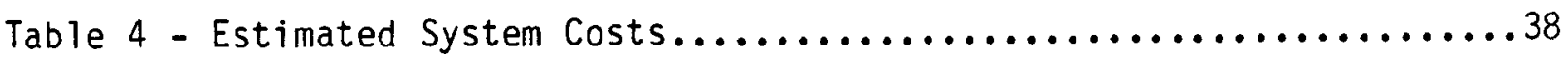




\subsection{EXECUTIVE SUMMARY}

The Phase I study of the geothermal potential of Ascension Island concluded that the possibility of a geothermal resource existing under the island was excellent. This conclusion was based on the presence of young volcanic rocks (a heat source close to the surface), an ample supply of water from the sea, and high permeability of many of the rocks which make up the island. The assumption was made that the resource would be similar to geothermal systems in the Azores or Japan, and a conceptual design of a power plant to utilize the resource was prepared upon which cost estimates and an economic analysis were subsequently performed. The results of the economic analysis were very favorable, and the Air Force decided to proceed into Phase II of the project.

Under Phase II, an exploration program was designed and carried out. The purpose of the program was to ascertain whether or not a geothermal resource existed beneath Ascension Island and, to the extent possible, to evaluate the quality of that resource. The exploration involved a detailed aeromagnetic survey of the island, reconnaissance and detailed electrical resistivity surveys, and drilling of holes for the measurement of temperatures. These methods have confirmed the existence of geothermal activity beneath Ascension. Measured temperature gradients and bottom hole temperatures as well as chemical geothermometers indicate temperatures sufficient for the generation of electricity within reasonable drilling depths. This report documents those conclusions and the supporting data.

This report also documents the results of the power plant update with new data supplied from the Phase II exploration activities on the island. The power plant scenario has been changed to reflect the fact that the resource 
temperature may not be as high as that originally assumed in the Phase I study, the location of the production wells will in all likelihood be farther from the existing Air Force facilities--either north of Grazing Valley or. south of Traveller's Hill--and the demand for power has increased which results in a more efficient utilization of the geothermal resource.

The power plant concept chosen is similar to that used for Phase I in that small, modular, skid-mounted, factory assembled and tested, units are used to supply the power and potable water. This Phase II concept is dissimilar in the following respects:

1. The power cycle best suited to the estimated resource temperatures is the organic Rankine or flash-binary cycle that uses heat transfer to a secondary power cycle fluid to produce the power (the Phase I power cycle was a flash-steam cycle).

2. Four $1 \mathrm{MW}(\mathrm{e})$ power units are located near the production wells rather than in the existing Air force power plant building.

3. Two production wells are needed to assure the ability to produce the required amount of power.

The capital cost for the Phase II concept is estimated to be $\$ 16,575,000$. Two cases were investigated for the economic analysis: Case 1 made the assumption that the electrical demand would permit three 1 MW(e) units to operate at a $90 \%$ capacity factor to produce $23,652,000 \mathrm{kWh} / \mathrm{yr}$ which left one unit on standby. The $7 \%$ discounted payback period for this case is 4.45 years. Case 2 made the optimistic assumption that all four of the 1 MW(e) units would be required, operating at a slightly reduced capacity factor of $87-1 / 2 \%$, giving $30,660,000 \mathrm{kWh} / \mathrm{yr}$. The existing diesel powered units would provide standby power. The $7 \%$ discounted payback period for this case is 3.49 years. In all cases the escalation rate for fuel and lube oil is assumed to be $4.6 \%$. 
Assuming that the projection for increased power requirements at Ascension Island are accurate, it is concluded that the Air Force should continue Phase II of the project by drilling a deep (5000 ft) test to allow for the confirmation of temperature and fluid flow characteristics of the reservoir. 


\subsection{RESOURCE ASSESSMENT}

\subsection{Geothermal Exploration}

The objective of the Phase II geothermal exploration of Ascension Island was to assess the possibility for a high-temperature geothermal resource beneath Ascension Island, and to identify areas which had the highest potential for the discovery of such a resource. In order to accomplish this, an exploration strategy was established in our Phase I technical report (Nielson and Sibbett, 1982). That strategy is shown on Figure 1, and the results of the various surveys shown in the strategy are outlined in detail in technical reports which have been submitted to the USAF (Ross et al., 1984a,b; Sibbett et al., 1984). The following sections will summarize these detailed technical reports and indicate the impact of each survey on our understanding of the geothermal resource.

The different methods which have been applied to the geothermal exploration of Ascension Island differ among themselves both from the standpoint of the physical properties measured and from their expense. The exploration began with a literature review followed by geologic mapping of the island (Fig. 1). These are some of the most cost-effective methods available, and resulted in the finding that Ascension Island had a high potential for the discovery of a geothermal resource, and the recommendation that the project should continue into Phase II. As part of the Phase II effort we completed aeromagnetic and electrical resistivity surveys on the island. The data from these surveys were used to locate temperature gradient drill holes. All of the surveys shown for Phase II (Fig. 1) have been carried out except the thermal IR survey. Equipment was not available for this survey; however, we feel that this did not adversely affect the successful completion of the Phase II 


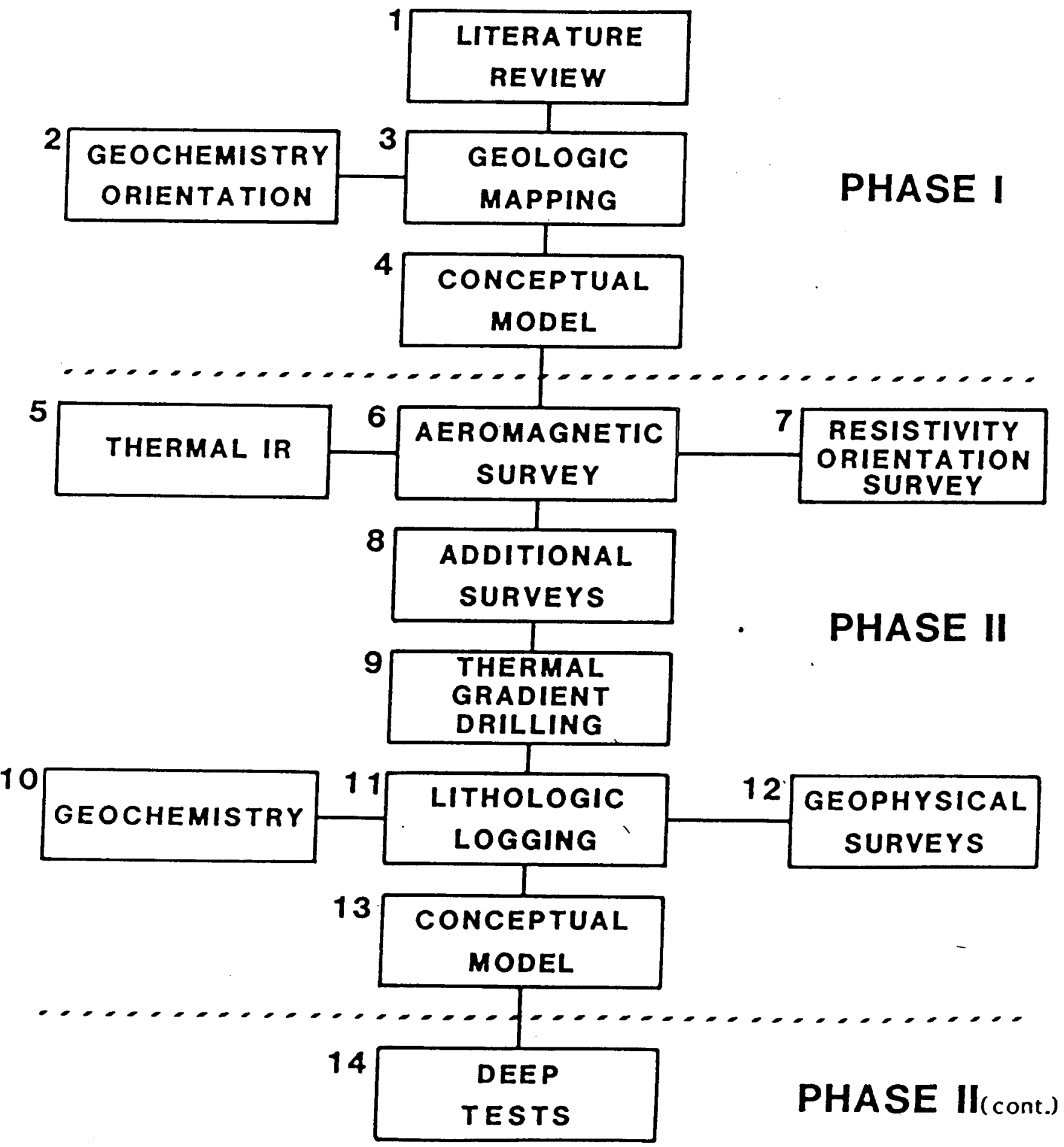

Figure 1. Exploration strategy for the Ascension geothermal project. 
effort.

The exploration for natural resources is an inherently risky task. However, by the application of a systematic exploration effort, with frequent updating of the exploration data base, many of these risks can be mitigated.

\subsubsection{Electrical Resistivity}

The results of the electrical resistivity surveys on Ascension Island have been reported in detail by Ross et al. (1984a). The electrical resistivity geophysical methods are used to measure the earth's resistivity, i.e. the ease with which the ground conducts electricity. Parameters that can cause changes in measured resistivity include porosity and permeability, amount of water, amount and type of dissolved salt, amount and nature of other fluids, and amount and nature of clay minerals present in the subsurface. The higher concentration of salts in geothermal fluids as well as their higher temperatures cause a lower earth resistivity. Zones of clay alteration produced by geothermal activity can also be detected and mapped by the low resistivity values associated with them.

Earth resistivity changes caused by thermal fluids and clays are mapped at the surface by deploying a system of four electrodes. A precisely controlled current is injected into the ground between two current electrodes, and a resulting voltage is measured between the two potential electrodes: The measured voltage is a function of the geometrical parameters of the electrode array, the magnitude of the injected current and the resistivity structure of the surrounding earth.

Reconnaissance electrical resistivity measurements which covered the central $13.5 \mathrm{sq}$ miles of the island were completed, and the results of these 
surveys are shown in Fig. 2. A broad zone of low apparent resistivity (15-25 sm) was mapped trending north-northeast from Devil's Riding School through the central part of the island toward Northeast Bay. Areas east of Riding School and northeast of Two Boats showed the lowest apparent resistivities (5-15 sm) within this broad ( 1.2 mile by 3.1 mile) zone.

Dipole-dipole surveys were completed which have refined the location, depth and intrinsic resistivity of the low resistivity zones (Ross et al.., 1984a). The profiles show high resistivities above sea level, with some resistive masses extending to considerable depth. Low-resistivity zones at depth are thought to result from sea water incursion within a few kilometers of the coast. Geothermal brines probably contribute to low-resistivity zones farther inland, i.e. from Devil's Riding School northeast toward the town of Two Boats. Resistivity survey work was difficult to complete where fresh lava flows give rise to high electrode impedance. As a result, the low resistivity zones remain incompletey defined. The low resistivity areas defined by the survey work were recommended for thermal gradient test drilling. Additional resistivity work would contribute to the optimum siting of a deep geothermal test or production well.

A single dipole-dipole resistivity line was completed north of Command Hill to determine the potential for a shallow fresh water table near the U.S. Base. The observed high-resistivity values were not favorable for the presence of a fresh water lens above the salt water zone. A recommendation was made that an alternate site be selected for the fresh water we11.

\subsubsection{Aeromagnetic Survey}

The results of an aeromagnetic survey of Ascension Island have been reported in detail by Ross et al. (1984b) and are shown in Figure 3 . The 
aeromagnetic method is a tool for locating buried fault and dike trends. These zones serve both as conduits for circulating geothermal fluids and as structural controls for the emplacement of dikes which can serve as heat sources for the geothermal system. The survey was run using a GeoMetrics Model G-803 Airborne Proton Magnetometer. The sensor is a toroidally wound coil immersed in a selected hydrocarbon fluid (kerosene) rich in protons. The sensor is mounted in an aerodynamically designed housing approximately 2.5 feet long which is commonly referred to as the "bird." The magnetometer console was mounted in a Wessex helicopter provided by the Royal Navy and connected to the sensor by a 100-foot long electrical cable with an exterior nylon sleeve strength member. Protons within the kerosene are polarized when a few amperes of current are passed through the coil surrounding the hydrocarbon fluid sample and align with the applied magnetic field. When this magnetic field is removed, the protons precess about the direction of the ambient (earth's) magnetic field at a rate proportional to the total magnetic intensity. The frequency of the precession signal is counted by the magnetometer. The magnetometer was operated at a sensitivity of 1.0 gamma corresponding to a sampling rate of 0.5 seconds, or a distance of 65 to 100 feet on the ground depending on true ground speed.

The primary flight-line directions were oriented $565^{\circ} \mathrm{E}$ directly into (or out of) the strong (20 knot) southeast trade winds to minimize drift off the intended flight path. Twenty-nine flight lines were completed at an average separation of 1240 feet. Eight tie lines were flown in a north-northeast direction, roughly perpendicular to the primary flight direction, at varying intervals across the entire island. The helicopter was flown on a smoothly draped flight path with a mean terrain clearance of 750 feet as monitored by the aircraft radar altimeter. An in situ magnetic susceptibility survey was 
also completed to assist in understanding the magnetic properties of Ascension rocks and aid in the interpretation of the aeromagnetic data.

The aeromagnetic survey has been interpreted using a three-dimensional numerical modeling program which computes the net magnetic field of a large number of vertically sided prisms. Multiple source bodies of complex geometry were modeled and modified until a general agreement was achieved between the observed data and the computed models.

The interpretation (Fig. 3) indicates northeast- and east-trending elongate bodies of much higher apparent susceptibility than adjacent rocks. The relation to mapped geologic features such as volcanic vents, dikes and faults suggests that these magnetic sources are zones of increased dike density, and other mafic intrusives emplaced along structures which fed the many volcanic centers.

Faulting is inferred along the margins of some magnetic sources, and at the termination of several sources near the center of the island. An irregular area of approximately $2.7 \mathrm{sq}$ miles within the center of the island (Fig. 3) is a low-magnetization area of considerable structural complexity. The low-magnetization area corresponds well with zones of low electrical resistivity mapped in earlier studies. This would appear to be the most likely area for the presence of a geothermal system at moderate depth (3000 to $9000 \mathrm{ft}$ ), and is included in the area recommended for additional exploration activity (Fig. 3)

\subsubsection{Thermal Gradient Drilling and Measurements}

The main component of the Phase II effort on Ascension Island was the drilling and completion of seven holes for the measurement of subsurface 


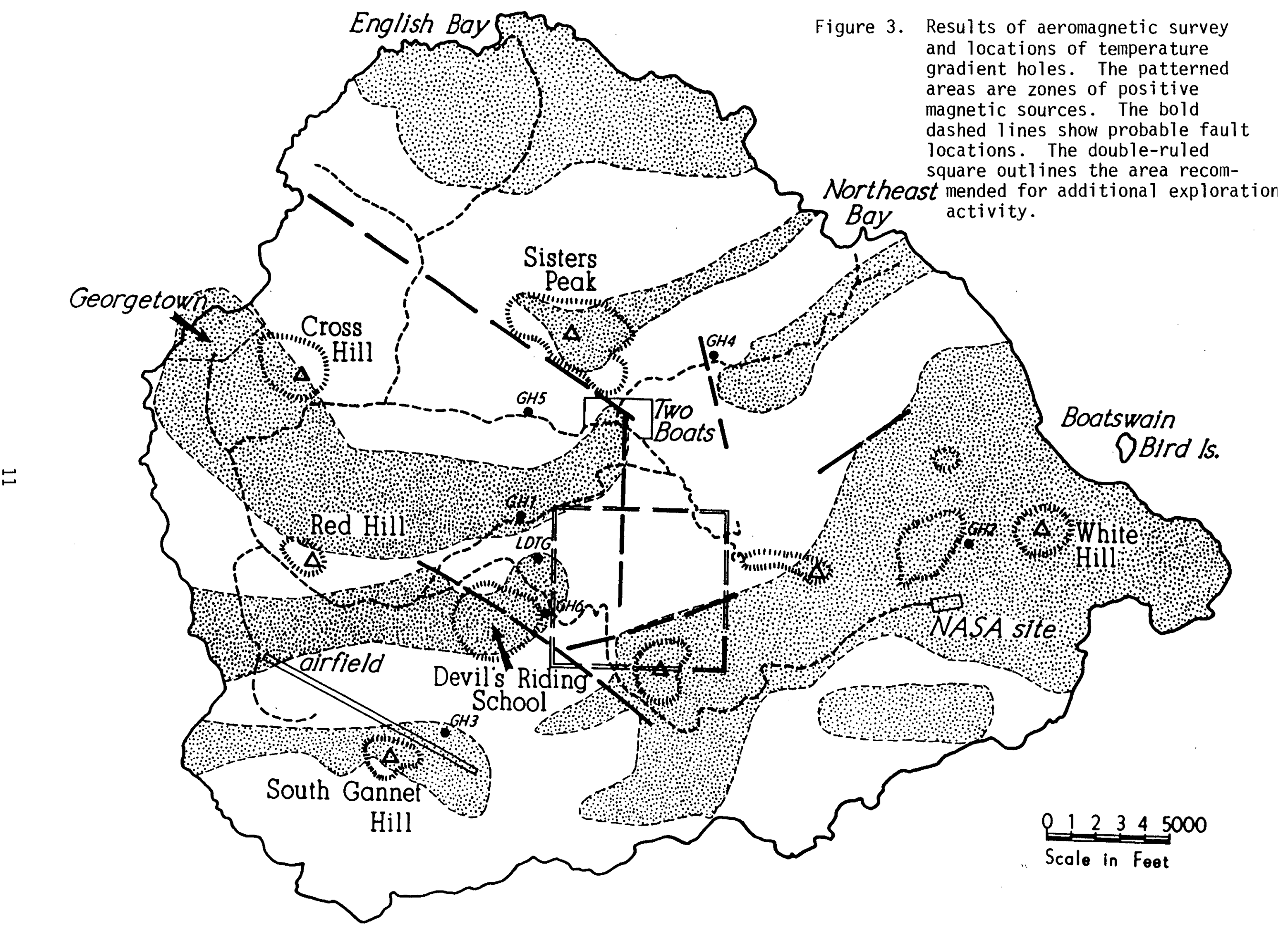


temperatures. The results of this work are documented in detail in Sibbett et a). (1984).

The drilling phase resulted in seven holes which range from 206 to 1750 feet deep, with a cumulative footage of 6,563 feet. The locations of these holes are shown in Figure 3. The drilling procedures and the problems encountered during the drilling have been explained in the more detailed report to provide valuable information for any subsequent drilling program on the island. In addition, the subsurface geology encountered in the holes has been documented and, where possible, correlated with other holes or the geology mapped on the surface of the island.

Temperatures measured in the holes reach a maximum of $130^{\circ} \mathrm{F}$ at 1285 feet in hole GH-6. When the temperatures of all holes are plotted against elevation (Fig. 4), the holes can be classed into three distinct groups, those which have no thermal manifestations, those with definite geothermal affinities, and one hole which is intermediate between the other two. From consideration of this information, it is clear that the highest geothermal potential on the island is in the Donkey Flat area beneath Middleton Ridge (the exploration area outlined in Figure 3) and in the Cricket Valley area. Because of the deeper drilling depths and the remote nature of the Cricket Valley area, it is recommended that future exploration concentrate in the area around Middleton Ridge.

Hole LDTGH was a large diameter hole which was drilled to test for the presence of a fresh water aquifer beneath the island. The water encountered was brackish. The absence of a fresh water lens is probably due to the high lateral permeability of the island which effectively disburses any precipitation to the sea. Fluid samples collected from this well have been chemically 


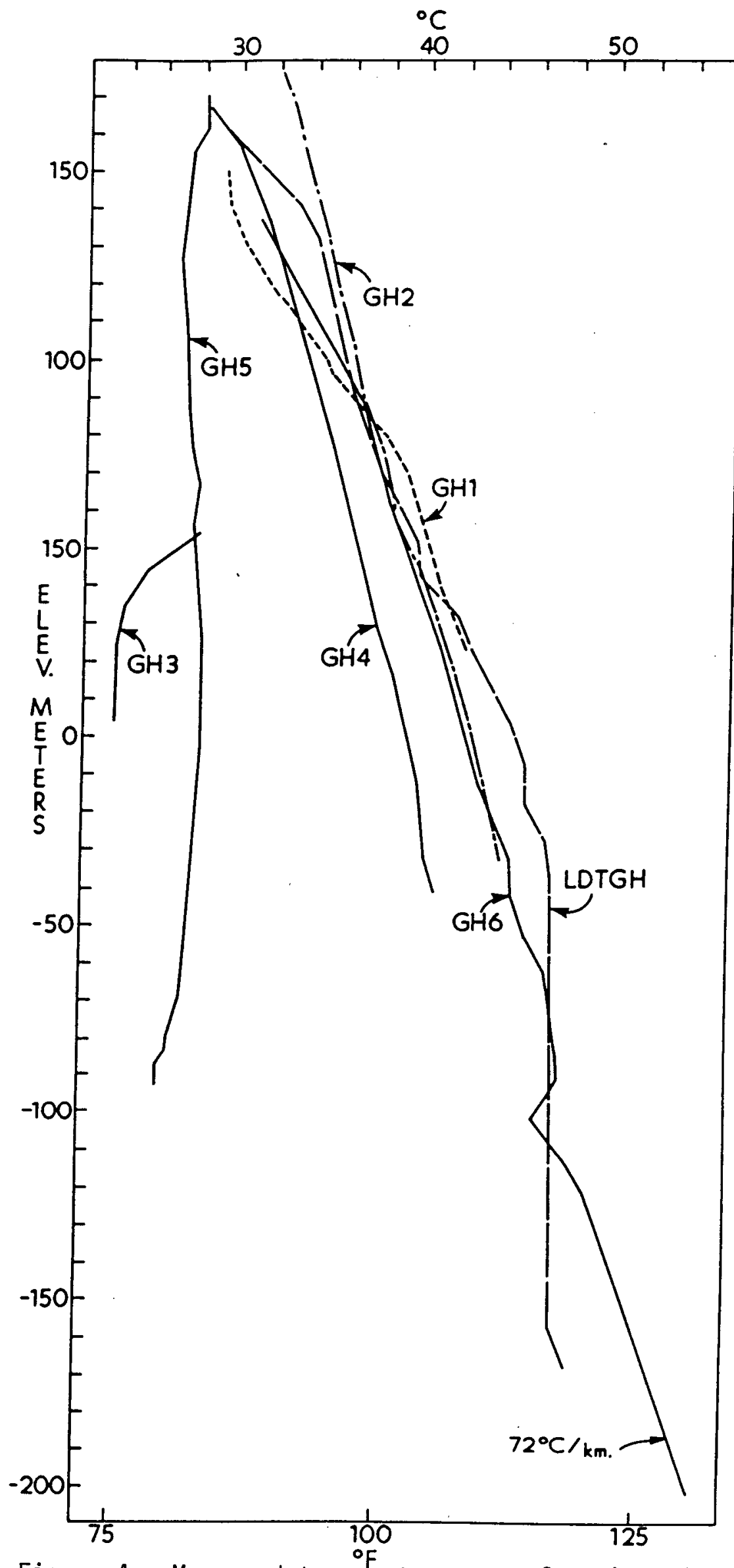

Figure 4. Measured temperature as a function of elevation for gradient holes drilled on Ascension Island.

13 
Table 1. Chemical Composition of Ascension Island Samples, Seawater and Seawater-Derived Geothermal Brine from Reykjanes, Iceland. Concentrations in $\mathrm{mg} / \mathrm{kg}$.

\begin{tabular}{ccccccccr} 
Sample \# & $573^{\prime}$ & $578^{\prime}$ & $599^{\prime}$ & $625^{\prime}$ & $625^{\prime} \# 1$ & $625^{\prime} \# 2$ & Reykjanes & Seawater \\
\hline Date of Collection & $3 / 12 / 84$ & $3 / 12 / 84$ & $3 / 12 / 84$ & $3 / 12 / 84$ & $3 / 13 / 84$ & $3 / 13 / 84$ & $\mathrm{nr}$ & $\mathrm{nr}$ \\
Temperature $\left(^{\circ} \mathrm{C}\right)$ & 45 & 45 & 45 & 45 & 45 & 45 & $269^{\circ} \mathrm{C}$ & $\mathrm{nr}$ \\
$\mathrm{Na}$ & 4,273 & 4,283 & 4,272 & 9,282 & 9,587 & 9,710 & 10,135 & 10,500 \\
$\mathrm{~K}$ & 167 & 166 & 165 & 318 & 327 & 331 & 1,480 & 380 \\
$\mathrm{Ca}$ & 419 & 433 & 435 & 608 & 538 & 544 & 1,628 & 400 \\
$\mathrm{Mg}$ & 584 & 586 & 578 & 1,169 & 1,202 & 1,222 & 1.0 & 1,350 \\
$\mathrm{Sr}$ & 3.24 & 3.24 & 3.24 & 6.76 & 6.94 & 7.03 & $\mathrm{nr}$ & 8 \\
$\mathrm{Fe}$ & 324 & 311 & 334 & 92 & 74 & 78 & $\mathrm{nr}$ & .01 \\
$\mathrm{Si} 0_{2}$ & 25 & 25 & 24 & 94 & 99.0 & 101 & 600 & 6.4 \\
$\mathrm{Li}$ & .13 & .14 & .13 & .22 & .22 & .22 & $\mathrm{nr}$ & .17 \\
$\mathrm{~B}$ & 1.84 & 1.84 & 1.79 & 2.71 & 2.72 & 2.76 & $\mathrm{nr}$ & 4.6 \\
$\mathrm{HCO}{ }_{3}$ & 15 & $<10$ & 13 & 86 & 119 & 225 & $\mathrm{nr}$ & 142 \\
$\mathrm{SO}{ }_{4}$ & 1,006 & 1,018 & 1,003 & 2,320 & 2,402 & 2,446 & 22.2 & 2,700 \\
$\mathrm{Cl}$ & 8,760 & 8,690 & 8,640 & 17,100 & 17,800 & 17,800 & 19,727 & 19,000 \\
$\mathrm{~F}$ & 2.40 & 2.00 & 2.10 & 2.40 & 2.70 & 2.70 & .1 & 1.3 \\
$\mathrm{~B}$ & 29 & $\mathrm{na}$ & $\mathrm{na}$ & $\mathrm{na}$ & $\mathrm{na}$ & 63 & $\mathrm{nr}$ & 65 \\
$\mathrm{Br}$ & 15,430 & 15,420 & 15,340 & 30,770 & 32,460 & 32,500 & $\mathrm{nr}$ & $\mathrm{nr}$ \\
$\mathrm{TDS}$ & 6.1 & 6.1 & 6.1 & 6.1 & 6.2 & 6.3 & $\mathrm{nr}$ & $\mathrm{nr}$
\end{tabular}

na $=$ not analyzed for, $\mathrm{nr}=$ not reported 
analyzed (Table 1), and those analyses indicate that they are derived from seawater reacting with rocks at elevated temperatures. Temperatures calculated from the chemical analyses indicate that the fluids have seen temperatures at least as high as $232^{\circ} \mathrm{F}$ and may have experienced temperatures between $302^{\circ}$ and $392^{\circ} \mathrm{F}$. We believe that these fluids have been transported laterally from the higher temperature portions of the thermal system and may not be the highest temperatures, which could be discovered by a deeper drilling program.

Estimates of the depth at which specific temperatures will be found are shown in Figure 5. They are based on measured gradients which for the area of interest. The bottom-hole temperatures for $\mathrm{GH}-1$ and $\mathrm{GH}-6$ are plotted on Figure 5. Using these values as starting points, lines of $60^{\circ} \mathrm{C} / \mathrm{km}, 70^{\circ} \mathrm{C} / \mathrm{km}$, and $80^{\circ} \mathrm{C} / \mathrm{km}$ have been plotted. These lines span the range of the higher temperature gradient measured in the drill holes. The average thermal gradient for North America is $30^{\circ} \mathrm{C} / \mathrm{km}$ and this curve is shown on Figure 5 for reference. These gradient lines assume a constant conductive heat flux and constant thermal conductivity with depth and are thus conservative estimates. In Icelandic holes an increase in thermal conductivity of $20 \%$ is recorded in holes up to $2 \mathrm{~km}$ deep. This would result in a decrease in the thermal gradient with depth. Conversely if future holes intersect the upwelling portion of a hydrothermal convection system, dramatic increases in temperature will be found.

\subsection{Data Synthesis}

The data from our exploration program have indicated that an area shown in the double-dashed lines of Figure 3 has the highest potential for the discovery of a geothermal resource. This area has a coincidence of the electrical resistivity lows, structural zones defined by the aeromagnetic 


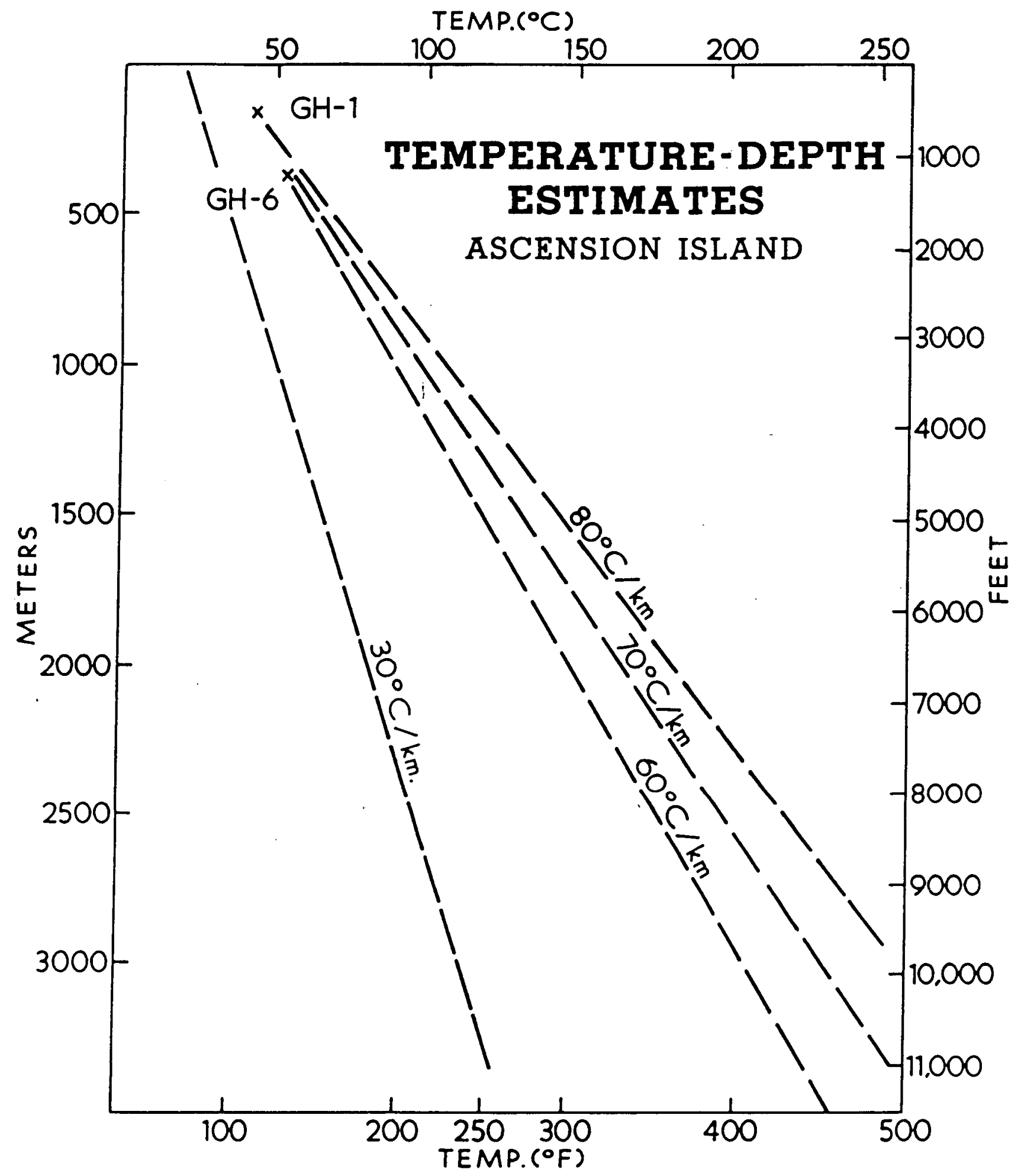

Figure 5. Estimates of temperature as a function of depth beneath Ascension Island $\left(60^{\circ} \mathrm{C} / \mathrm{km}-80^{\circ} \mathrm{C} / \mathrm{km}\right)$ based on the results of thermal gradient drilling. The $300 \mathrm{C} / \mathrm{km}$ gradient is the average thermal gradient for North America. 
survey, and high temperatures recorded in the thermal gradient drill holes.

From all the data collected, we have arrived at two possible conceptual models of the geothermal system beneath Ascension Island (Fig. 6). In Figure 6a, a high-temperature geothermal system with temperatures up to $392^{\circ} \mathrm{F}$ rises to sea level and then moves laterally. As the fluids move, they cool both by conduction to the surrounding rock and by mixing with meteoric fluids and unheated sea water. A second possibility is shown in Figure $6 \mathrm{~b}$. This shows a high-temperature geothermal convection system which heats the overlying fluid zone by conduction. This overlying fluid is heated to temperatures of at least $232^{\circ} \mathrm{F}$. It also moves laterally away from the zone of greatest heating and is mixed with both meteoric waters and sea water. The highest temperatures in the central portion of this system could reach $500^{\circ} \mathrm{F}$ or more.

Our estimates of geothermal reservoir parameters are given in Table 2. The estimates of temperature as a function of depth are based on extrapolation of the highest temperature gradients measured in the existing holes. These are conservative estimates based on what we presently know about the geothermal system. Values for pressure, permeability and fluid chemistry shown in Table 2 are based on knowledge of geothermal systems in similar environments, principally Iceland. The data shown in Table 2 have been applied to the update of the economics of the geothermal power plant, which will be discussed in the following section. 


\section{ASCENSION GEOTHERMAL PROJECT \\ POSSIBLE MODELS}

(a)

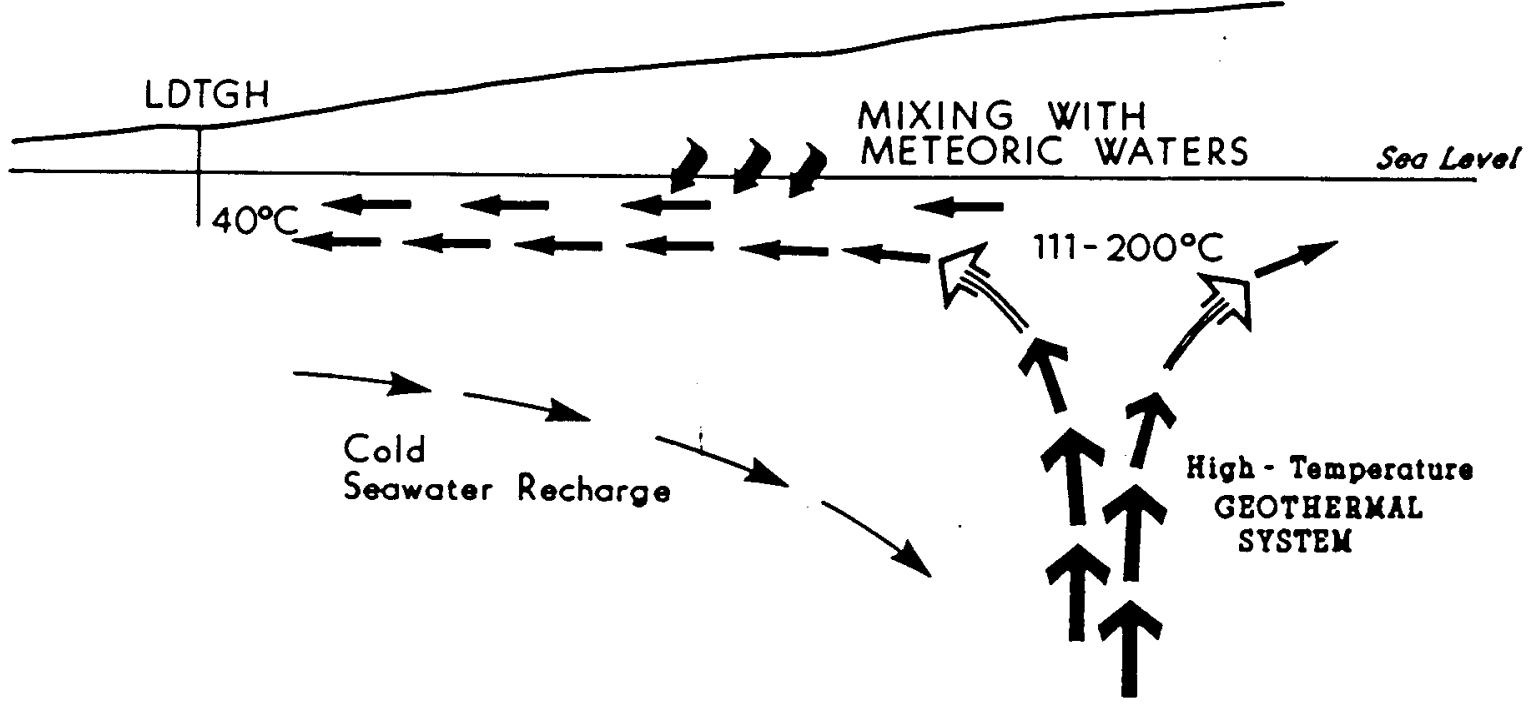

(b)

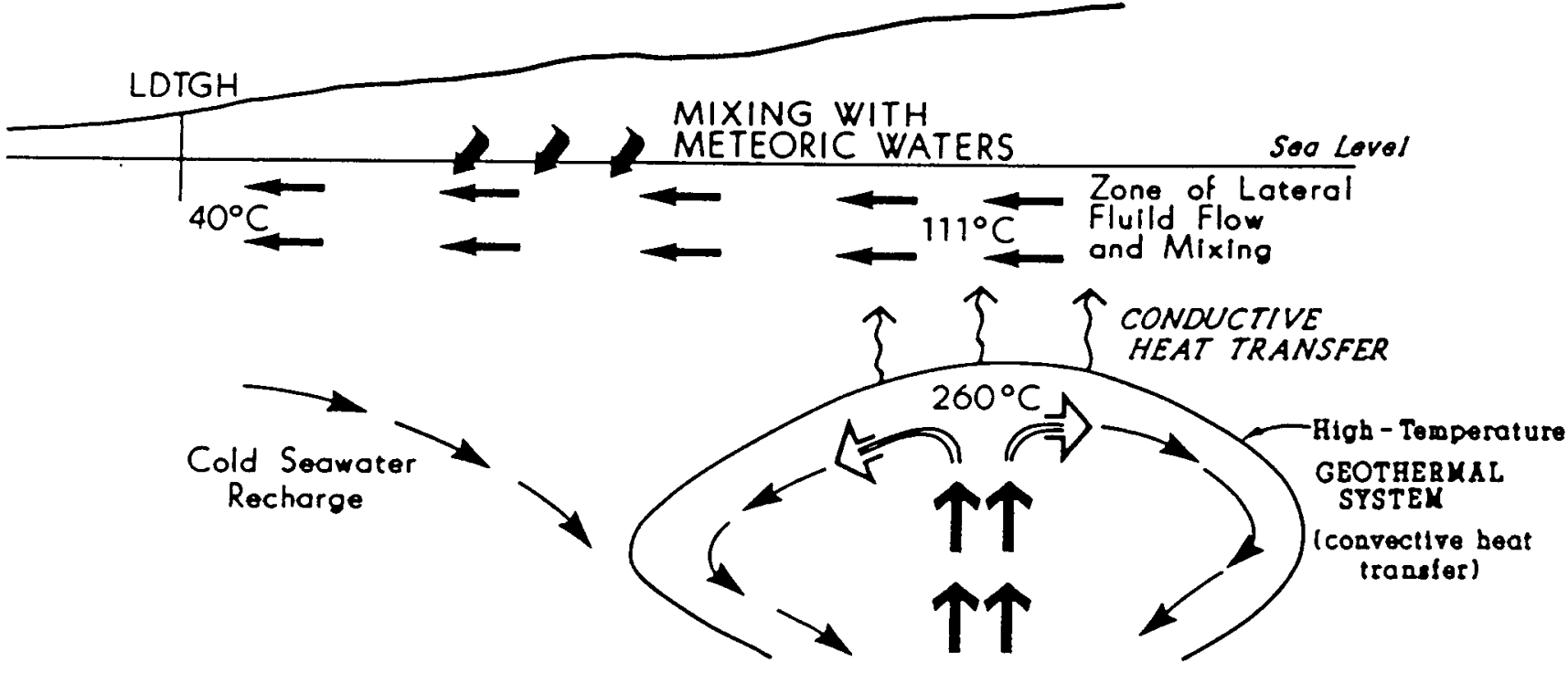

Figure 6. Conceptual models of the geothermal system beneath Ascension Island. 
Table 2. Estimates of Geothermal Reservoir Parameters, Ascension Island

$\begin{array}{ccccc}\begin{array}{c}\text { TEMPERATURE } \\ { }^{\circ} \mathrm{F}\end{array} & \begin{array}{c}\text { DEPTH } \\ \text { (Feet) }\end{array} & \begin{array}{c}\text { PRESSURE } \\ (\text { BARS) }\end{array} & \begin{array}{c}\text { PERMEABILITY } \\ \text { MILLIDARCYS }\end{array} & \begin{array}{c}\text { TDS } \\ \text { PPM }\end{array} \\ 212 & 2953 & 91 & 80 & 35000 \\ & 3855 & 118 & 75 & 35000 \\ 250 & 4000 & 123 & 75 & 35000 \\ & 5085 & 156 & 70 & 35000 \\ 400 & 7546 & 232 & 50 & 35000 \\ & 9678 & 298 & 40 & 35000 \\ 550 & 11,000 & 338 & 20 & 35000 \\ & 14,190 & 437 & 20 & 35000\end{array}$




\subsection{GEOTHERMAL POWER PLANT UPDATE}

\subsection{Background}

During Phase I, site requirements for power and potable water were examined, resource development options were studied, and a system concept was prepared on which cost estimates and an economic analysis were based (Sibbett et al., 1982). For the purposes of the Phase I study, assumptions had to be made concerning the geothermal resource, supply system, power plant, potable water and cooling water systems. The most important assumption was that a resource would be found that was similar to that developed at the Azores north of Ascension Island on the Mid-Atlantic Ridge. The resulting conceptual design used the resource to generate $2 \mathrm{MW}(\mathrm{e})$ of baseload electrical power for the U.S. airbase and also produced up to 100,000 gallons per day of potable water from a flash-steam plant's condensate system. Backup and peaking power were provided by existing diesel powered generators. This scenario involved one production well, which was located about 1-1/2 miles from the existing power plant and produced $346,620 \mathrm{lb} / \mathrm{hr}$ of geothermal fluid at $410^{\circ} \mathrm{F}$, which was separated into steam and brine fractions at the wellhead. Steam fraction was used to power two $1 \mathrm{MW}(\mathrm{e})$ self-contained, factory assembled and tested, skid mounted geothermal steam-turbine/generators which were housed in the existing Air Force power plant. Cooling water was pumped from the ocean to a condenser located at the power plant and returned to the ocean along with the brine fraction of the geofluid for disposal. Capital cost in 1982 dollars was estimated at $\$ 11.5 \times 10^{6}$, and this included the Phase II exploration cost of $\$ 780,000$. A $7 \%$. discounted payback of 5.9 years was calculated for the baseline geothermal plant. Parametric analysis of the more probable uncertainties gave paybacks which only rose to 7.8 years, and it was concluded that 
there was financial justification for the Air Force to continue into Phase II of the project.

Subsequent to the Phase I studies, the U.S. Air Force requested that a brief study be performed to look at the feasibility of increasing the capacity of the power plant because of a forecast of a change in the electrical demands at the base. The configuration evaluated consisted of three $1 \mathrm{MW}(\mathrm{e}) \mathrm{high}$ pressure steam-turbine/generators and one low pressure steam-turbine/generator that would produce between 0.8 and $1.2 \mathrm{MW}(\mathrm{e})$, dependent upon the output characteristics of the one geothermal production well. Simultaneous operation of two high pressure turbines and the one low pressure turbine was assumed which left one high pressure turbine/generator in reserve. Assumptions concerning the geothermal resource, production well location, turbine/ generator location and seawater cooling system were unchanged from the Phase I study. The capital cost for this system in 1982 dollars, consistent with the Phase I study, was estimated to be $\$ 15 \times 10^{6}$ for all costs beyond Phase II.

Two economic analyses were run on the upgraded plant: Case 1 with the assumption that electrical demand would permit plant operation at an average of $2.8 \mathrm{MW}(\mathrm{e})$ with a $90 \%$ capacity factor gave a discounted payback period of 5.1 years, slightly better than the 5.9 years of the original study; Case 2 , where the electrical demand was only 2 MW(e) with a $90 \%$ capacity factor, allowed the additional generating capacity to sit idle a significant portion of the year and showed a 7.7 year discounted payback period.

After authorization was received to proceed with Phase II, the Earth Science Laboratory of the University of Utah Research Institute drilled several shallow wells on the island to gain further insight into the geological structure than could be derived from surface inspection and to obtain 
preliminary temperature gradient information. The results of these investigations are presented in this report and in Sibbett et al. (1984). An extrapolation of shallow well temperature gradient was used to obtain an "expected" temperature as a function of depth (Fig. 5). These extrapolations are based on observed gradients and provide a basis for investigating the type of power plant needed, the maximum well depth required and an estimate of the economics of the project.

It should be understood that the results presented, because of the extreme projection of the shallow well temperature gradients, represent only another, but less optimistic, data point than that assumed for the Phase I study.

\subsection{Resource Development and Use}

Site requirements have changed since the Phase I study inasmuch as the power requirements for the U.S. Air Force system are now considered to be 3 $\mathrm{MW}(\mathrm{e})$ average and $3.5 \mathrm{MW}(\mathrm{e})$ peak. Potable water requirements remain at a maximum of 47,000 gallons/day. Based upon the estimated temperatures and well depth forecasts from the Phase II shallow well results, a new power plant scenario has been developed which utilizes a binary system for production of the necessary power from a lower temperature resource and still produces the required potable water. Estimated temperatures and well depth requirements are discussed, and the effect of a production zone that is further inland (north of Grazing Valley or south of Traveller's Hill--see Figure 7) is reflected in the power plant design and economic analysis.

Figure 5 provides projections of temperature as a function of depth for three assumed gradients: $60^{\circ} \mathrm{C} / \mathrm{km}, 70^{\circ} \mathrm{C} / \mathrm{km}$, and $80^{\circ} \mathrm{C} / \mathrm{km}$. These gradients 


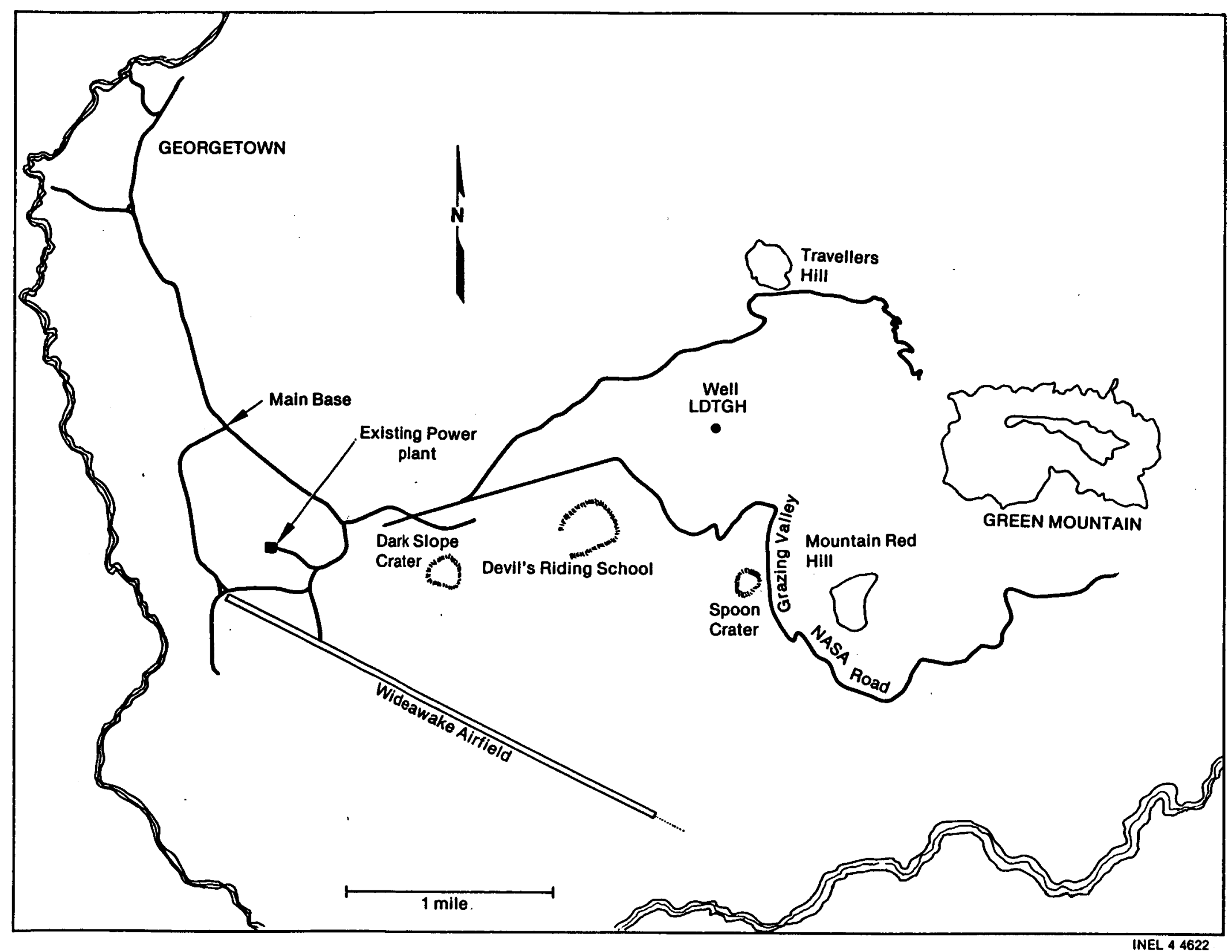

Figure 7. Index map of a portion of Ascension Island. 
represent crude estimates in lieu of having data from a deep hole. Although power plants can be made to operate, theoretically, with a resource temperature slightly above the sink temperature, economics related to each situation dictate the actual resource requirements. As depth increases, temperature increases, resulting in an increased power output per pound of geothermal fluids; however, the cost of the well also increases. Therefore, there will be a depth and associated temperature that will lead to a minimum cost of power. Using relationships presented in Sibbett et al. (1982) for well cost versus depth and the $70^{\circ} \mathrm{C} / \mathrm{km}$ gradient curve of Figure 5, Figure 8 was derived. In Figure 8, the fractional change in the cost of electricity (COE), delta COE/COE, is plotted against depth. The maximum occurs at about 7800 ft. At this depth the resource temperature is estimated to be about $375^{\circ} \mathrm{F}$.

\subsubsection{Power Cycle Options and Assumptions}

The selection of a geothermal power cycle is strongly influenced by the resource temperature, and to a lesser degree by the availability of cooling water, scale forming tendency of the geothermal fluid and its dissolved gas content. In general, flash-steam systems are more economical if the resource temperature is above about $400^{\circ} \mathrm{F}$ and binary systems are more economical if the resource temperature is below $400^{\circ} \mathrm{F}$. The Phase I power plant studies, which were based on an assumed resource temperature over $400^{\circ} \mathrm{F}$, considered the use of a flash-steam plant to provide both power and potable water.

Since the optimum temperature is estimated to be less than $400^{\circ} \mathrm{F}$, a binary cycle has been selected for this Phase II analysis. EG\&G has considerable experience in the analysis of binary cycles (Demuth, 1981, 1983; Bleim and Kochan, 1981; Demuth and Kochan, 1981; Demuth and Whitbeck, 1982), and it was relatively easy to adapt these analyses to the power plant at Ascension 


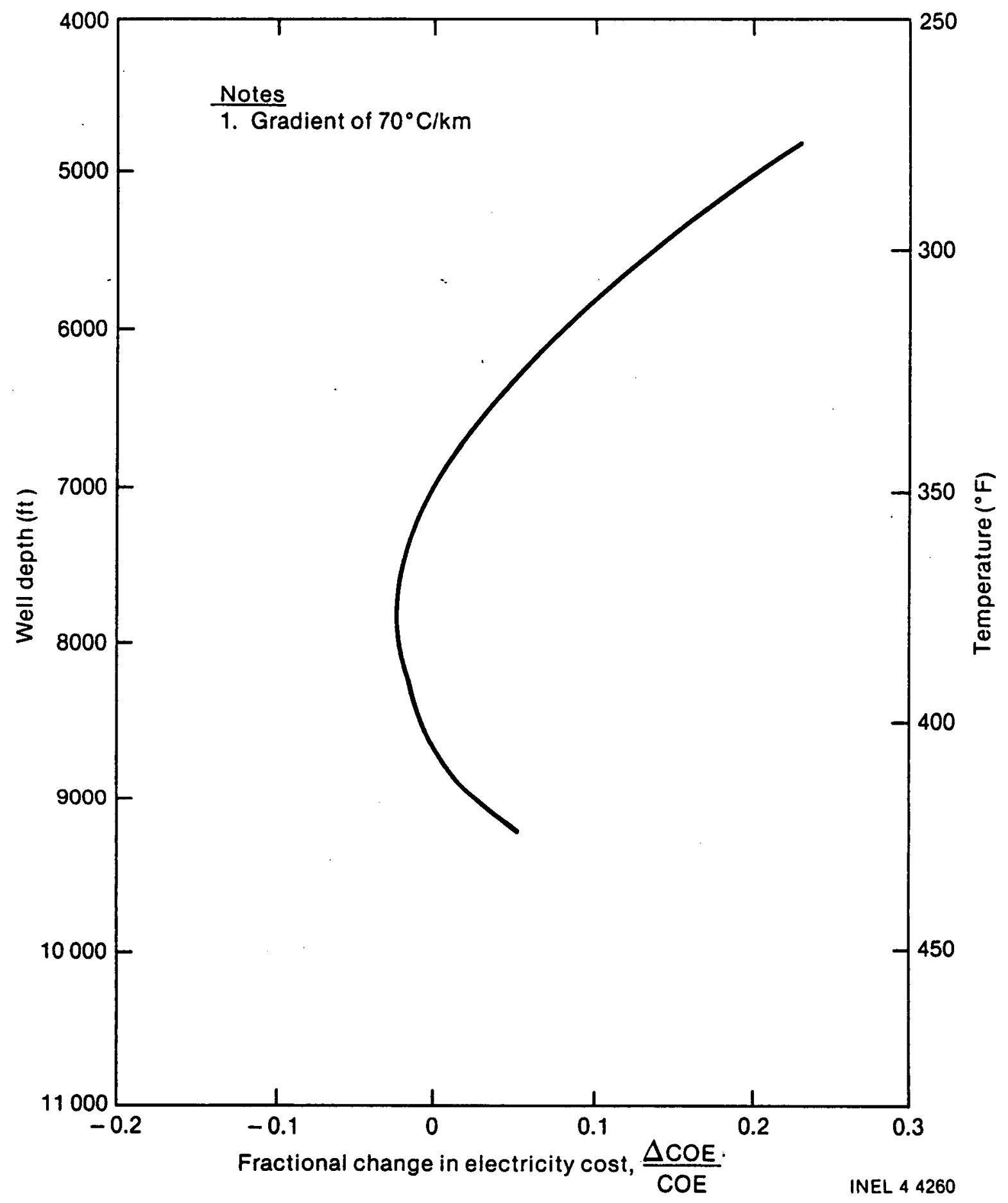

Figure 8. Well depth versus fractional change in cost. 
Island.

In addition to resource temperature and other considerations mentioned above, the power cycle must be tailored to fit the Air Force requirements for the system and site specific conditions. The following is a summary list of basic assumptions used to define the power cycle:

Geothermal temperature at inlet

Silica deposition temperature limit

Dissolved gas content

Geothermal pressure at inlet

Heat rejection (condenser)

Make-up water

Design wetbulb temperature

Power cycle working fluid

Potable water requirement

Power requirement per unit

\section{$365^{\circ} \mathrm{F}$}

None at this time

Neglected

265 psi

Evaporative condenser

Brackish water from existing well and excess potable water

$81^{\circ} \mathrm{F}$

Isobutane

$47,000 \mathrm{gpd}$

$1 \mathrm{MW}($ net ).

The bases for these are summarized in the following discussion.

Geothermal temperature at inlet. The optimum well depth was determined to be between about $7400 \mathrm{ft}\left(365^{\circ} \mathrm{F}\right)$ and $8200 \mathrm{ft}\left(380^{\circ} \mathrm{F}\right)$ (see Figure 8). Assuming some minor temperature drop from the wells to the plant, the inlet to the plant was assumed to be $365^{\circ} \mathrm{F}$.

Silica deposition temperature limit. Silica solubility is primarily a function of temperature but is also affected by $\mathrm{pH}$ and equilibrium with other constituents of the geothermal fluid. Rather than impose an arbitrary geothermal outlet temperature limit to prevent deposition which in time may limit performance, no restriction was assumed since other evaluations have shown (Bleim and Kochan, 1981) that performance loss due to imposing this limit can be eliminated by proper selection of the working fluid and recuperation. 
Dissolved gas content. The dissolved gas content is unknown. The amount and type of dissolved gas will affect the set depth of the well pump but will not significantly affect its power requirement. If the dissolved gas is significant, a pressurized vent tank will be employed upstream of the plant in which the geothermal pressure will be allowed to approach saturation pressure thereby permitting release of the dissolved gas. This would minimize the impact of the dissolved gas on heat transfer.

Geothermal pressure at inlet. The 265 psi assumed for the plant inlet is based upon maintaining the fluid subcooled and in addition providing sufficient pressure to overcome pressure losses in the power plant units.

Heat rejection (condenser). Because the high wetbulb condition and a desire to maintain good performance, an evaporative condenser was selected. This selection reduces the condensing temperature on the order of $20^{\circ} \mathrm{F}$ compared to the condensing temperature that would be achieved with a standard forced draft cooling tower.

Make-up water. If the power plant units are located in the vicinity of the Large Diameter Thermal Gradient Hole (LDTGH), this well may be capable of supplying make-up needs. The advantages of using water from a well near the new plant as compared to using sea water are: (1) a long line (several miles) from the sea is not required, and (2) biological fouling by organisms present in sea water is eliminated. Since the plant considered in this evaluation will produce more potable water than is required, the excess can be used to dilute the brackish well water.

Power cycle working fluid. Isobutane has been selected as the reference working fluid because a large amount of information is available on this 
fluid. Mixtures of isobutane with other light hydrocarbons do not significantly increase performance (for a flash-binary cycle), however, when a detailed plant analysis is conducted, they may prove to be desirable. Certain fluorocarbons can provide similar performance. Thus, the use of isobutane will provide representative results.

Potable water requirement. Air Force requirements are for $47,000 \mathrm{gpd}$. Several options are available for meeting this requirement, and they should be considered after more specifics are known about the reservoir. The flashbinary power cycle assumed for this study will produce about 140,000 gpd. The excess will be used as make-up for the evaporative condenser and considered as a resource should requirements for potable water increase. In a more detailed evaluation which includes trade-off studies, an overall benefit may result by using the higher performance binary systems which are possible if flashing of the geothermal fluid is not required in the production of potable water.

The power cycle schematic shown on Figure 9, the cycle state points given in Table 3, and the power cycle diagram shown in Figure 10 are for a unit producing about $1 \mathrm{MW}$ net and a heat exchanger pinch point of $10^{\circ}$ minimum. Each unit will require about $380 \mathrm{gpm}$ of geofluid. Since three units will be required to satisfy the average load requirements, a total well flow of about $1140 \mathrm{gpm}$ will be required. The system defined will have a geofluid utilization factor of about 6 watt-hrs/lb of geofluid. Slightly higher performance (say $\sim 10 \%$ ) may be possible through the use of mixtures but they were not considered in this study. Substantially higher utilization factors, on the order of 7.5 watt-hrs/lb ( $-25 \%)$ would be possible if flashing of the geothermal fluid was not required to produce potable water. However, if the potable water $(47,000 \mathrm{gpd})$ was to be produced by a stream separate from that supplying 


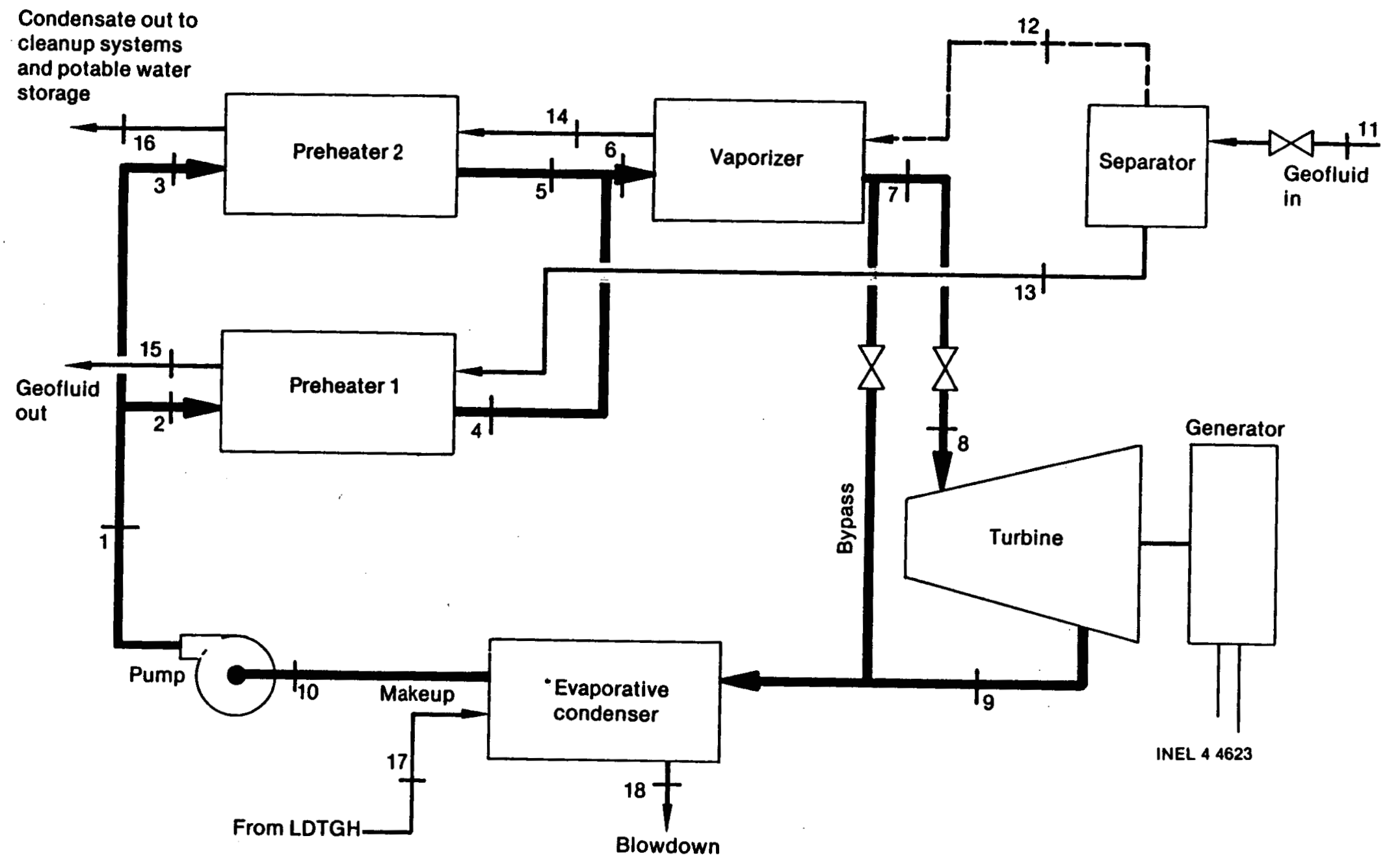

Figure 9. Power cycle schematic. 
Table 3. Power Cycle State Points.

\begin{tabular}{|c|c|c|c|c|}
\hline $\begin{array}{l}\text { State } \\
\text { Point } \\
\end{array}$ & Fluid & $\begin{array}{l}\text { Flow, Rate } \\
\mathrm{lb} / \mathrm{hr} \\
\end{array}$ & $\begin{array}{c}\text { Temperature } \\
{ }_{0} \mathrm{~F}\end{array}$ & $\begin{array}{l}\text { Pressure } \\
\text { (psia) } \\
\end{array}$ \\
\hline $\begin{array}{l}1 \\
2 \\
3 \\
4 \\
5\end{array}$ & $\begin{array}{l}\text { Isobutane } \\
\text { Isobutane } \\
\text { Isobutane } \\
\text { Isobutane } \\
\text { Isobutane }\end{array}$ & $\begin{array}{l}240,000(900 \mathrm{gpm}) \\
209,250 \\
30,750 \\
209,250 \\
30,750\end{array}$ & $\begin{array}{l}113.5 \\
113.5 \\
113.5 \\
230 \\
230\end{array}$ & $\begin{array}{r}395 \\
395 \\
395 \\
-- \\
--\end{array}$ \\
\hline $\begin{array}{c}6 \\
7 \\
8 \\
9 \\
10\end{array}$ & $\begin{array}{l}\text { Isobutane } \\
\text { Isobutane vapor } \\
\text { Isobutane vapor } \\
\text { Isobutane vapor } \\
\text { Isobutane liquid }\end{array}$ & $\begin{array}{l}240,000 \\
240,000 \\
240,000 \\
240,000 \\
240,000\end{array}$ & $\begin{array}{l}230 \\
230 \\
230 \\
140 \\
110\end{array}$ & $\begin{array}{r}-- \\
346 \\
346 \\
83 \\
83\end{array}$ \\
\hline $\begin{array}{l}11 \\
12 \\
13 \\
14\end{array}$ & $\begin{array}{l}\text { Geo. liquid } \\
\text { Geo. vapor } \\
\text { Geo. liquid } \\
\text { Geo. liquid } \\
\text { (condensate) } \\
\text { Geo. liquid }\end{array}$ & $\begin{array}{r}167,000(380 \mathrm{gpm}) \\
21,000 \\
146,000 \\
21,000 \\
146,000\end{array}$ & $\begin{array}{l}365 \\
250 \\
250 \\
250\end{array}$ & $\begin{array}{r}165 \\
30 \\
30 \\
--\end{array}$ \\
\hline $\begin{array}{l}16 \\
17 \\
18\end{array}$ & $\begin{array}{l}\text { Geo. vapor cond. } \\
\text { Make-up } \\
\text { Blowdown }\end{array}$ & $\begin{array}{l}21,000 \\
50,000 \\
16,800\end{array}$ & $\begin{array}{l}128 \\
128 \\
128\end{array}$ & $\begin{array}{l}-- \\
-- \\
--\end{array}$ \\
\hline & \multicolumn{4}{|c|}{ Energy Balance, 1 MW unit } \\
\hline & pump work & $0.85 \times 10^{6} \mathrm{Btu} / \mathrm{hr}$ & & \\
\hline & preheaters & $20.26 \times 10^{6}$ & & \\
\hline & vaporizer & $19.2 \times 10^{6}$ & & \\
\hline & & $\overline{40.41 \times 10^{6}}$ & & \\
\hline & Gross work & $4.63 \times 10^{6}$ & & \\
\hline & Heat rejected & $35.78 \times 10^{6}$ & & \\
\hline
\end{tabular}




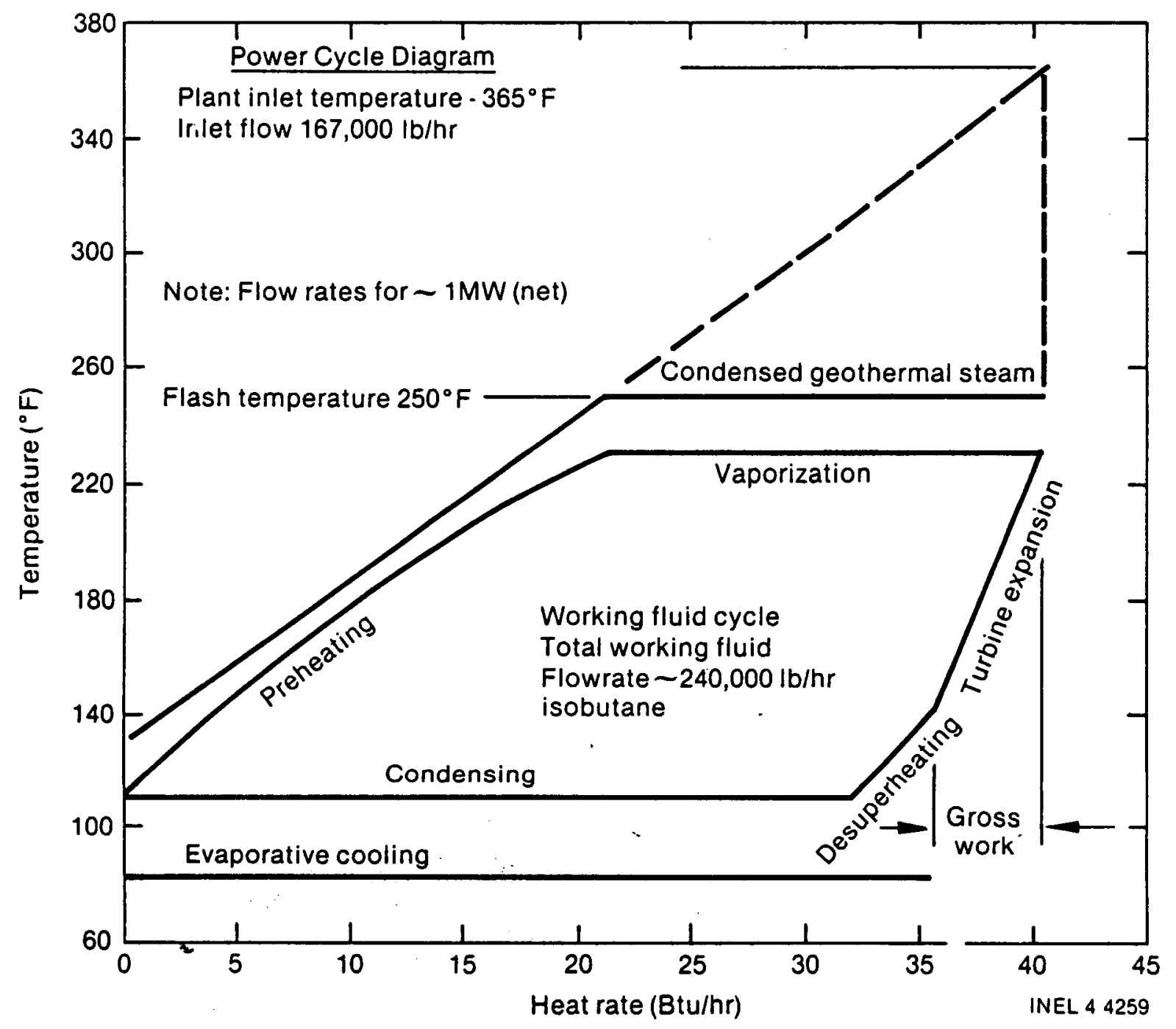

Figure 10. Power cycle diagram. 
the power plant, little change in the total geothermal flow requirement would result, and any decision to pursue that option would be governed by other considerations, for example independence of systems or heat exchanger fouling.

\subsubsection{Baseline System Description}

After resolving the power cycle options, work proceeded on the conceptual design of a complete system that would satisfy the necessary functional requirements so that project costs could be estimated and an economic assessment performed. Figure 11 is a schematic flow diagram of the baseline system. 3.2.2.1 Geothermal Supply System

The most recent information concerning the probable location of the resource is that it will be in the vicinity of Well LDTGH--north of Grazing Valley or south of Traveller's Hill (see Figure 7). For sizing and estimating purposes, it was assumed that two wells would be required and that they were each one-half mile from the new power plant (1 mile apart with the power plant located at the mid-point). Downhole pumps were assumed as a requirement at each well to keep the geofluid from flashing in the wellbore or in the piping to the degassing tank and separator located at the new power plant. The pipes selected for the geofluid lines were 8 in, schedule 20 carbon steel. They would be laid above grade on supports every $19 \mathrm{ft}$. Horizontal 1oops would be provided at intervals to accommodate thermal expansion and contraction. The lines would be insulated with 2 in thick fiberglass and be jacketed with a luminum.

\subsubsection{Power Plant System}

The flash-binary power units are skid mounted, modular units which have been preassembled and tested as subsystems at the factory. In the field, the skids are installed on concrete pads and prefabricated piping is installed between skids. Several manufacturers in the U.S. and Japan are involved in 


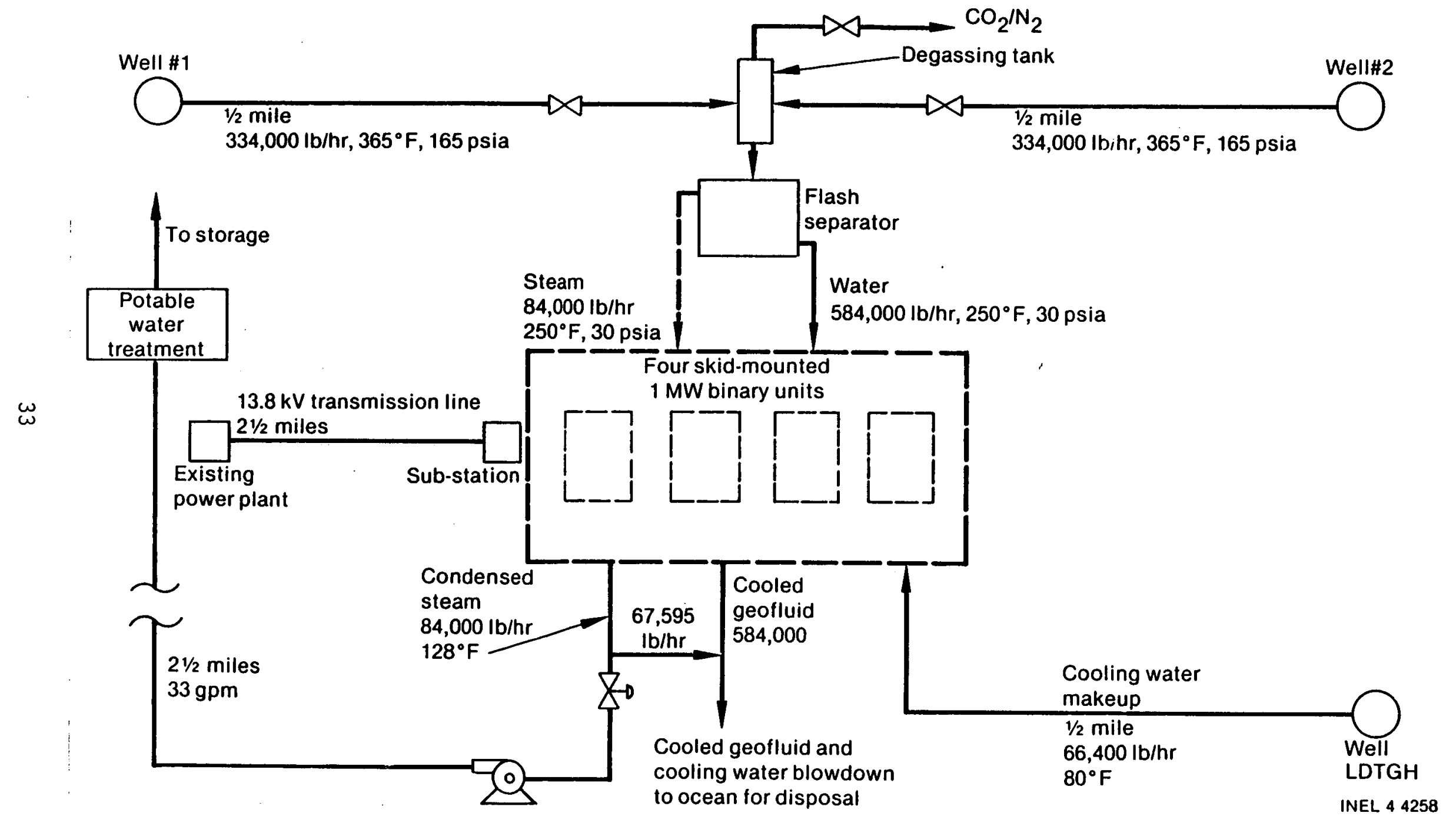

Figure 11. Baseline system flow schematic. 
the design and manufacture of binary power units as described. Controls are provided with the units to provide for automatic system startup and operation.

To get an idea of size and weight of individual subassemblies, the following information was supplied by one of the manufacturers as being typical for a 2 MW(e) "Power Generation Module" (Barber-Nichols Engineering).

2 subassemblies $10 \mathrm{ft} W \times 40 \mathrm{ft} \mathrm{L} \times 10 \mathrm{ft} H \quad 55,000 \mathrm{lb}$ each (max)

4 condenser fan $10 \mathrm{ft} W \times 21 \mathrm{ft} L \times 8-1 / 2 \mathrm{ft} H \quad 7,000$ lb each sections

4 condenser coil $10 \mathrm{ft} W \times 21 \mathrm{ft} \mathrm{L} \times 7-1 / 2 \mathrm{ft} H \quad 27,000 \mathrm{lb}$ each sections

Miscellaneous inter-

10,00016

connecting piping and hardware

The evaporative condenser fan and coil sections are stacked on the two main subassemblies at the site on final assembly, so a crane is required for this operation. The height of the power unit module after final assembly is about $26 \mathrm{ft}$.

The major components of each of the $1 \mathrm{MW}(\mathrm{e})$ power unit modules are shown on Figure 9, and the balance of the equipment is shown on Figure 10. The four skid mounted binary unit modules, the degassing tank, the flash separator, and the substation are all located in the same area, about $1 / 2$ mile from each of the production wells and $1 / 2$ mile from Well LDTGH. It was also assumed that this location would be about $2-1 / 2$ miles from the existing power plant.

Geothermal fluid pumped from either of the production wells will first go to a vent tank operating near the saturation pressure corresponding to the fluid temperature. The fluid will degas under this condition allowing the 
evolved gas to be vented to the atmosphere. The geothermal fluid will then pass into a steam separator controlled to about 165 psig which will produce about $13 \%$ steam and this corresponds to $21,0001 \mathrm{~b} / \mathrm{hr}$ per unit at the total geothermal flow of $167,000 \mathrm{lb} / \mathrm{hr}(380 \mathrm{gpm})$ per unit. This steam will be condensed in the vaporizer as it vaporizes the working fluid. The condensate will be cooled as it preheats a portion of the working fluid. The sensible heat in the geothermal liquid from the separator will be used to preheat the rest of the working fluid.

On the working fluid side, $113^{\circ} \mathrm{F}$ liquid isobutane will be pumped to two preheaters at a pressure of about $395 \mathrm{psig}$. The flow split between the preheaters will be about 8 to 1 and is determined by the amount necessary to cool the geothermal steam condensate. The outlets of both preheaters will be joined prior to entering the vaporizer. Vapor temperatures and pressure will be $230^{\circ} \mathrm{F}$ and $330 \mathrm{psig}$. The working fluid would then pass through the turbine to the evaporative condenser.

Electric power from the generators will be transformed at the substation to a transmission 1 ine voltage of $13.8 \mathrm{kV}$ and routed to the $13.8 \mathrm{kV}$ distribution bus in the existing power plant.

\subsubsection{Cooling Water System}

The evaporative condenser must be provided with sufficient water to make up for losses due to evaporation and blowdown. It has been assumed that this water can be supplied from Well LDTGH and from excess condensate from the plant if dilution of the brackish well water is required.

Water from well LDTGH would be pumped through about $1 / 2$ mile of 4 in schedule 40 carbon steel pipe. As with lines from the production wells, the pipe would run above ground and be supported on piers spaced $14 \mathrm{ft}$ apart. 
This line will not be insulated but it will need to be coated for weather protection. If terrain permits, the final design might utilize transite or CPVC for this pipe.

\subsubsection{Potable Water System}

The potable water is produced from steam which has been condensed to water in the vaporizer and preheater number 2. As the quality of the condensate is unknown at this time, a water treatment system has been included in the design to remove any objectionable dissolved gases or minerals. This water treatment system is expected to be a small "polishing station" that requires very little in the way of maintenance or chemicals to perform its intended function. Location of the "polishing station" would be at the existing power plant site.

Piping from the new power plant site to the existing power plant site would be through 3 in schedule 40 carbon steel supported above grade every 12 ft. Again, the possibility exists that CPVC could be used in the final design.

After the treatment at the "polishing station," the potable water would be pumped to the existing potable water storage tanks for storage and distribution.

\subsubsection{Waste Water System}

The ideal waste water disposal system would consist of a line discharging the used geothermal fluid and cooling water blowdown to one of the nearby craters such as Spoon Crater or Dark Slope Crater--thereby creating "Crater Lake." However, as the pros and cons of this option are unknown, it was assumed that the waste water would have to be piped to the ocean for disposal. If all four of the binary units are operating, this flow amounts to about 1450 
gpm and can be handled with an 8 in schedule 20 carbon steel line, installed above grade with steel ladder-type supports at $19 \mathrm{ft}$ intervals. The pipe must be protected against the weather, so a protective coating has been assumed as a requirement. Also included in the assumptions for the waste water disposal was a small hydroelectric unit at the ocean to recover some of the power used in pumping.

\subsubsection{Baseline System Costs and Economics}

The estimated system costs in 1984 dollars are shown on Table 4. In arriving at these costs, the following assumptions were used:

1. All construction materials must be shipped in

2. Construction material costs are stateside plus shipping

3. Construction equipment is available on the island

4. Construction Tabor and equipment costs are the same as stateside

5. Materials and equipment are shipped by sea

6. The production wells and binary cycle turbine/generators are GFE.

The total project cost, following the initial exploration, is estimated to be $\$ 16,575,000$, and this includes two production wells and four $1 \mathrm{MW}(\mathrm{e})$ binary units complete with all equipment necessary for the production of the required power and potable water as described in detail in Section 3.2 . The cost of the binary units is based upon representative costs obtained from potential suppliers of packaged units, and the cost of the production wells is based upon an estimate from historical well cost data.

To calculate project economics, it was assumed that three of the four 1 MW(e) units would be used to provide baseload power, and the fourth unit would 
TABLE 4: ASCENSION ISLAND POWER PLANT (4-1 MW(e) BINARY UNITS WITH POTABLE WATER SUPPLY)

\begin{tabular}{|c|c|c|c|c|}
\hline & $\begin{array}{l}\text { Contractor } \\
\text { Equipment }\end{array}$ & Labor & Tota I & GFE \\
\hline $\begin{array}{l}\text { Production Wells and Testing ( } 2 \text { wells) } \\
\text { Structures and Imp rovements } \\
\text { TG foundations } \\
\text { Potable water treatment } \\
\text { Cooling water pumphouse } \\
\text { Brine pond } \\
\text { Total }\end{array}$ & & & $\begin{array}{r}100,000 \\
176,000 \\
40,000 \\
5,000 \\
321,000\end{array}$ & $6,860,000$ \\
\hline $\begin{array}{l}\text { Geothermal Supply system } \\
\text { Supply piping and pumps } \\
\text { Wellhead I \&C } \\
\text { IBcC I Ines } \\
\text { Wellhead separator } \\
\text { Miscellaneous } \\
\text { Total }\end{array}$ & $\begin{array}{l}70,000 \\
50,000\end{array}$ & $\begin{array}{l}24,000 \\
10,000\end{array}$ & $\begin{array}{r}562,100 \\
94,000 \\
10,000 \\
60,000 \\
50,000 \\
776,100\end{array}$ & $\overline{6,860,000}$ \\
\hline $\begin{array}{l}\text { Power Plant } \\
\text { Turb ine generators } \\
\text { Vent tank } \\
\text { Disconnect breaker } \\
\text { Transformer } \\
\text { Transmission line } \\
\text { Valve fittings } \\
\text { Miscellaneous } \\
\text { Total }\end{array}$ & $\begin{array}{r}30,000 \\
80,000 \\
50,000 \\
120,000 \\
25,000\end{array}$ & $\begin{array}{r}200,000 \\
10,000 \\
12,000 \\
10,000 \\
12,500\end{array}$ & $\begin{array}{r}200,000 \\
40,000 \\
92,000 \\
60,000 \\
120,000 \\
37,500 \\
100,000 \\
649,500\end{array}$ & $\begin{array}{l}4,000,000 \\
4,000,000\end{array}$ \\
\hline $\begin{array}{l}\text { Cooling water system } \\
\text { Pump } \\
\text { Piping } \\
\text { Valves, fittings, and supports } \\
\text { rotal }\end{array}$ & $\begin{array}{l}50,000 \\
25,000\end{array}$ & 25,000 & $\begin{array}{r}50,000 \\
67,000 \\
50,000 \\
167,000\end{array}$ & \\
\hline $\begin{array}{l}\text { Waste System } \\
\text { Hydraulic turbine generator } \\
\text { Waste water piping } \\
\text { Total }\end{array}$ & 287,000 & 86,000 & $\begin{array}{r}373,100 \\
380,000 \\
753,100\end{array}$ & \\
\hline Equipment Shipping & & & 200.000 & \\
\hline
\end{tabular}


TABLE 4. (continued)

\begin{tabular}{|c|c|c|c|c|}
\hline & $\begin{array}{l}\text { Contractor } \\
\text { Equipment }\end{array}$ & Labor & Total & GFE \\
\hline $\begin{array}{l}\text { Total project direct and shipping } \\
\text { Indirect }(15 \%) \\
\text { Profit (10\% of direct and indirect) } \\
\text { Tota I construction (direct and indirect) } \\
\text { Construction management (12\% of total } \\
\text { construction) } \\
\text { Total construction and construction } \\
\text { management } \\
\text { Design } \\
\text { Project management } \\
\text { Tota) } \\
\text { Contingency ( } 25 \%) \\
\text { GFE (including indirect) } \\
\text { Tota) Project }\end{array}$ & & & $\begin{array}{r}2,866,700 \\
430,000 \\
329,700 \\
3,626,400 \\
435,200 \\
4,061,000 \\
260,000 \\
250,000 \\
4,571,600 \\
1,143,400 \\
10,860,000 \\
16,575,000\end{array}$ & \\
\hline
\end{tabular}


automaticaliy come on line if the peak power exceeds $3 \mathrm{MW}(\mathrm{e})$. The wells and generators will be remote from the power plant, but there is no requirement for any operator actions at the well site. It was assumed that the plant would be operated and maintained by the same labor force as used in the existing operation.

In 1983, the Air Force charged a base cost of $\$ 1.26$ per gallon for the JP5 fuel used at Ascension Island. However, there was an additional diversion cost of $\$ 0.36$ per gallon to get fuel to the island for a total of $\$ 1.62$ per gallon. The 1983 charge for lube oil was $\$ 3.35$ per gallon. In FY 1983 , $1,253,880$ gallons of diesel fuel and 9416 gallons of lube oil were used to produce $15,883,840 \mathrm{kWh}$. This converts to $\$ 0.13 / \mathrm{kWh}$ in 1983 dollars for fuel and lube oil.

Two economic analyses were run on the binary plant, and the economic impact of $7 \%$ discounted payback vs. $10 \%$ discounted payback for each case was investigated. Case 1 made the assumption that the electrical demand would permit three $1 \mathrm{MW}(\mathrm{e})$ units to operate at a $90 \%$ capacity factor to give $23,652,000 \mathrm{kWh} / \mathrm{yr}$. The $7 \%$ discounted payback period for this case is 4.45 years, and the $10 \%$ discounted payback period is 4.84 years. Case 2 made the optimistic assumption that all four of the $1 \mathrm{MW}(\mathrm{e})$ units would be required, operating at a slightly reduced capacity factor of $87-1 / 2 \%$, giving $30,660,000$ kWh/yr. The $7 \%$ discounted payback period for this case is 3.49 years, and the $10 \%$ discounted payback period is 3.73 years. In a11 cases the escalation rate for fuel is assumed to be $4.6 \%$. 


\subsection{CONCLUSIONS AND RECOMMENDATIONS}

The Phase II geothermal exploration of Ascension Island has demonstrated the existence of a geothermal system which may be of sufficient quality to produce electrical power. We know that the fluid temperature reaches $130^{\circ} \mathrm{F}$ (GH-6) and have interpreted the temperature logs as demonstrating some amount of lateral transport of the fluid. There does not seem to be evidence for thermal upwelling in the vicinity of GH-6 and LDTGH as would be expected if the hole were directly over a convecting hydrothermal system. We also know that the fluid sampled at LDTGH has seen temperatures of at least $232^{\circ} \mathrm{F}$, and possibly as high as $392^{\circ} \mathrm{F}$. The principal problem in arriving at an accurate maximum temperature is that the chemistry of any fluids which mixed with the thermal fluid is unknown.

Because of the addition of a second production well to assure reliability of the system under increased demands for power, the capital cost for this Phase II system concept is higher than any considered previously. However, the increased utilization of the geothermal resource with its attendant fuel and lube oil savings resulted in project payback periods that are very attractive.

In order to test the deeper portions of this geothermal system we recommend an additional electrical resistivity survey in the area of Middleton Ridge. This survey will allow us to target a deep temperature gradient hole which will be drilled to a depth of 3000 to 5000 feet to test the temperature and fluid flow characteristics of the deeper portion of the geothermal system. The results of this hole would allow a decision to be made concerning the drilling of production wells and the development of a power plant and electrical distribution system. 


\subsection{ACKNOWLEDGEMENTS}

The success of this project is due in large part to the enthusiasm of several individuals who provided their expertise and the logistic support of their organizations under difficult field conditions. These people are George Hotchco and Lt. Col. Walter White, USAF; and William Koslow, Wayne Rollins and Tom DeLeat of Pan American World Services. 


\subsection{REFERENCES}

Bliem, C. J., and Kochan, R. J., 1981, Power cycle studies for a geothermal electric power plant for MX operating bases: EGG-GTH-5684.

Demuth, 0. J., 1981, Analysis of mixed hydrocarbon binary thermodynamic cycles for moderate temperature geothermal resources: EGG-GTH-5733.

Demuth, 0. J., 1983, Effects of vaporizer and evaporative-condenser size on geofluid effectiveness and cost of electricity for geothermal binary power plants: EGG-GTH-0376.

Demuth, 0. J., and Kochan, R. J., 1981, Analysis of mixed hydrocarbon binary thermodynamic cycles for moderate temperature geothermal resources using regenerative techniques: EGG-GTH-5710.

Demuth, 0. J., and Whitbeck, J. F., 1982, Advanced concept value analysis for geothermal power plant: EGG-GTH-5821.

Kestin, J., DiPippo, R., Khalifa, H. E., and Ryley, D. J., eds., 1980, Sourcebook on the Production of Electricity from Geothermal Energy: DOE/RA/4051-1, 997 p.

Nielson, D. L., and Sibbett, B. S., 1982, Technical report-geothermal potential of Ascension Island, South Atlantic Phase I - Preliminary Examination: Earth Science Lab/UURI report to USAF and U.S. DOE, 79 p.

Ross, H. P., Green, D. J., Sibbett, B. S., and Nielson, D. L., 1984a, Electrical resistivity surveys, Ascension Island, South Atlantic Ocean: Earth Science Lab/UURI report to USAF and U.S. DOE, $33 \mathrm{p}$.

Ross, H. P., Nielson, D. L., and Green, D. J., 1984b, Interpretation of aeromagnetic survey, Ascension Island, South Atlantic Ocean: Earth Science Lab/UURI report to USAF and U.S. DOE, $37 \mathrm{p}$.

Sibbett, B. S., Nielson, D. L., Ramsthaler, J. H., and Shane, M. K., 1982, Geothermal potential of Ascension Island, South Atlantic, Phase I Preliminary Examination, Report No. IDO-10110, 54 p.

Sibbett, B. S., Nielson, D. L., and Adams, M. C., 1984, Thermal gradient driling program, Ascension Island, South Atlantic Ocean: Earth Science Laboratory/UURI report to USAF and U.S. DOE. 